\title{
Coexistence of Rheumatoid Arthritis and Familial Mediterrean Fever: $A$ Case Report and Review of the Literature
}

Romatoid Artrit ve Ailesel Akdeniz Ateşi Birlikteliği: Bir Olgu Sunumu ve Literatürün Gözden Geçirilmesi Betül Sargın ${ }^{1}$

1 Physical Medicine and Rehabilitation Department, Division of Rheumatology, Medical Faculty of Adnan Menderes University, Aydın/Turkey

\section{$\ddot{O Z E T}$}

Ailesel Akdeniz Ateşi (AAA), 12-72 saat süren tekrarlayan ateş, lökositoz, serozit, miyalji, erizipel benzeri cilt lezyonları ile karakterize en yaygın görülen monogenik otoinflamatuvar hastalıktır. Romatoid artrit (RA) kronik, sistemik inflamatuvar bir hastalıktır. En belirgin özelliği simetrik ağrı, el, el bilekleri, ayak ve dizlerdeki şişliktir. FMF ve RA' in bir arada bulunmasının altında yatan kesin mekanizmalar daha önce bildirilmemiştir. Bu yazıda FMF ve RA'lı hastayı sunmayı ve konu ile ilgili literatürü gözden geçirmeyi amaçladık.

Anahtar Kelimeler: birliktelik, Ailesel Akdeniz Ateşi, romatoid artrit

\section{ABSTRACT}

Familial Mediterranean Fever (FMF) is the most prevalent monogenic autoinflammatory disease characterized by clinical features of recurrent episodes of fever, leukocitosis, serositis, myalgia, erysipelas-like skin lesions, lasting 12-72 hours. Rheumatoid arthritis $(R A)$ is a chronic, systemic inflammatory disease. The most prominent feature is symmetrical pain and swelling of the hands, wrists, feet, and knees. The exact mechanisms underlying the coexistence of FMF and RA has not been reported previously. So far, only 8 cases of the coexistence of FMF and RA have been reported. In this report, we aimed to explain the association between FMF and RA and report one more case of this coexistence.

Keywords: coexistence, Familial Mediterranean Fever, rheumatoid arthritis

\section{INTRODUCTION}

Rheumatoid arthritis (RA) is a chronic autoimmune systemic inflammatory disease with a prevalence of $1 \%$ around the world. It varies among different populations (1). The etiology of RA includes genetic risk factors, environmental factors, and autoantibodies. One of the important genetic risk factors for the development of RA is epitope alleles in the MHC class II region. Smoking, viral, and bacterial infections are other environmental risk factors for RA (2). Familial Mediterranean Fever (FMF) is a hereditary autoinflammatory disease associated with gene mutations on chromosome $16 \mathrm{p} 13.3$ that encodes the pyrin (marenostrin) (3). IL-1 $\beta$ is the key inflammatory cytokine in FMF pathogenesis (4). Defective pyrin (marenostrin) activates caspase- 1 , which has a role in the conversion of pro-IL-1 $\beta$ to actively secreted IL-1 $\beta$ (4). The coexistence of RA and FMF has been rarely reported in the literature (511). The association is thought to be due to cytokine Networks (12). In this report, we aimed to present the patient with FMF and RA and review of literature about the topic.

\section{CASE}

A 47-year-old female patient was admitted to our clinic with complaints of pain, swelling, and morning stiffness in both wrists, right ankle, and left knee lasting approximately 45 minutes. The patient had complaints for 4 months. The patient had a diagnosis of FMF for 2 years. The patient had intermittent abdominal pain, fever up to $39-40^{\circ} \mathrm{C}$, and chest pain. Also, she had pericardial fluid on echocardiography. Abdominal attacks accompanied by fever were intermittent character and had been resolved within 3-4 days. Abdominal pain and fever attacks were recurring every 2-3 months. In addition, her mother had a diagnosis of FMF. Also, the patient's fever and abdominal pain attacks regressed with colchicine treatment. With these findings, FMF was diagnosed with Tel-Hashomer criteria (13). There was no consanguineous marriage. There was no family history of RA in the patient's history. When we evaluated in terms of psoriasis, both the patient and her relatives did not have psoriatic rash or dactylitis at present or in the

Yazışma Adresi/Address for Correspondence: Betül Sargın, MD, Medical Faculty of Adnan Menderes University, Department of Physical Medicine and Rehabilitation, Division of Rheumatology, Aydın, Turkey 
past. Locomotor system examination revealed arthritis of both wrists, right ankle, and left knee.

Her laboratory tests were as follows: Erythrocyte sedimentation rate (ESR) was $27 \mathrm{~mm} / \mathrm{h}, \mathrm{C}$-reactive protein (CRP) was $2(0-0,8) \mathrm{mg} / \mathrm{dL}$, rheumatoid factor (RF) was 9,8 $\mathrm{U} / \mathrm{mL}$ (normal range: 3-18 U/mL), and anti-citrullinated protein antibody (anti-CCP) was 179,8 U/mL (normal range:0-4,99 U/mL). The biochemical and urine analysis were within normal ranges. She was diagnosed with RA due to joint involvement, high positive anti-CCP level, abnormal ESR, and symptom duration of more than 6 weeks according to the 2010 American College of Rheumatology/European League Against Rheumatism (ACR/EULAR) (14). We excluded the diagnosis of RA due to the FMF phenotype, as the arthritis did not respond to colchicine treatment (15). The methylprednisolone (12 $\mathrm{mg} /$ day), sulfasalazine (2 g/day), and methotrexate (10-15 $\mathrm{mg} /$ week) were started for RA (16). The patient, whose complaints regressed with treatment, is still under followup in our clinic.

\section{DISCUSSION}

FMF is a chronic disease that has harmful effects on all aspects of quality of life (QoL) (17). Bodur et al. reported the first study which assessed QoL in FMF patients using the FMF-QoL Scale (18). As reported in this study our patient was female sex, which was associated with QoL in FMF.

Asymmetrical non-destructive arthritis, migratory polyarthritis, and chronic destructive arthritis are some of the arthritic patterns in FMF (19). The coexistence of RA and FMF was reported rarely (5-11). Previously, 8 cases with RA and FMF have been reported in the literature (Table 1) (511). All of the patients were female. Among them, eight patients had fever attacks, two (25\%) had chest pain, one (12.5\%) had abdominal pain and two had musculoskeletal pain. All of the patients fulfilled the Tel-Hashomer criteria for FMF (13). M694V mutation was positive in 3 patients, E148Q mutation was positive in 2 patients, and R202Q was positive in one patient. E148Q compound mutation was positive in 2 patients and R314R and M694l heterozygous mutations were positive in one patient. All of these patients were fulfilled both 2010 ACR/EULAR classification criteria for RA and FMF according to Tel-Hashomer criteria (13-14).
Our patient fulfilled FMF and RA according to RA and FMF diagnostic criteria (13-14). Different pathogenetic mechanisms play role in these two diseases. Multiple genetic and environmental factors have been associated with an increased risk for RA (2). MEFV gene mutations are responsible for FMF pathogenesis. MEFV gene encodes abnormal pyrin (marenostrin) protein. As a result of pyrin activation caspase- 1 and therefore active pro-inflammatory $\mathrm{IL}-1 \beta$ releases (4). The cytokine networks involved in the pathogenesis of FMF are similar to RA (12).

Koga et al. evaluated serum samples of 28 FMF patients diagnosed according to Tel-Hashomer criteria and 84 clinically active RA patients who met the 2010 ACR/EULAR criteria for RA (12-13-14). Koga et al.'s study reported that serum interleukin 6 (IL-6), IL-10, and granulocyte-colonystimulating factor (G-CSF), concentrations were significantly increased in the FMF attack group compared to FMF patients in remission (12). And they speculated that the cytokine network in the FMF attacks and active RA were similar. Previous studies have demonstrated that MEFV mutations have pathogenic roles in the development of RA $(11,20)$. Matsuoka et al. reported two RA patients with MEFV mutation in exon 2, who was diagnosed with FMF at an age of over 50 years (11). In their report first case was diagnosed with FMF at 75 years of age, and the second case experienced a lack of efficacy of multiple disease-modifying antirheumatic drugs (DMARDs) at the age of 52. They announced MEFV mutations modulate RA disease activity. They recommended that examining MEFV mutation and suspecting the complication of FMF in difficult cases of RA is important. Later, Inanir et al. investigated $5 \mathrm{MEFV}$ gene mutations (M694V, M680I, V726A, E148Q, and P369S) in 101 patients with RA and 110 healthy controls (20). They found that carrier rates of MEFV gene mutations were 31 (30.7\%) of 101 and 26 (23.6\%) of 110 in RA and healthy control groups, respectively $(p>0.05$; odds ratio, $1.4 ; 95 \% \mathrm{Cl}, 0.77$ 2.65). Their study results suggested that MEFV gene mutations were not positively associated with a predisposition to developing RA but might increase the severity of RA. The exact mechanisms underlying the coexistence of RA and FMF are still unclear. We need more evidence to speculate the pathogenic mechanisms about this rare association. 
Table 1. Summary of systematic review of the patient's rheumatoid arthritis with Familial Mediterranean Fever

\begin{tabular}{|c|c|c|c|c|c|c|c|}
\hline References & Age & Sex & FMF related symptoms & FMF mutation analysis & RF & Anti-CCP & Treatment \\
\hline $\begin{array}{l}\text { Turan } \\
\text { et } a .^{5}\end{array}$ & 48 & $\mathrm{~F}$ & $\begin{array}{l}\text { Abdominal pain, fever } \\
\text { attacks }\end{array}$ & M694V homozygote mutation & $\begin{array}{l}\text { Positive; } \\
412 \mathrm{IU} / \mathrm{ml}\end{array}$ & Positive & $\begin{array}{l}\text { Methotrexate, } \\
\text { Prednisolone, } \\
\text { Colchicine }\end{array}$ \\
\hline $\begin{array}{l}\text { Mori } \\
\text { et al. }{ }^{6}\end{array}$ & 60 & $\mathrm{~F}$ & $\begin{array}{c}\text { Fever episodes }\left(>38^{\circ}\right) \text {, severe } \\
\text { pain in the right hip joint }\end{array}$ & $\begin{array}{c}\text { E148Q heterozygous } \\
\text { mutation }\end{array}$ & $(-)$ & $\begin{array}{l}\text { Positive; } \\
57 \mathrm{IU} / \mathrm{mL}\end{array}$ & $\begin{array}{l}\text { Tacrolimus, } \\
\text { Methotrexate, } \\
\text { Colchicine }\end{array}$ \\
\hline $\begin{array}{l}\text { Migita } \\
\text { et al. }{ }^{7}\end{array}$ & 51 & $\mathrm{~F}$ & $\begin{array}{l}\text { Recurrent episodes of high } \\
\text { fever }\left(\geqslant 38^{\circ}\right)\end{array}$ & $\begin{array}{c}\text { E1480/G304R/P369S/ } \\
\text { R4080) compound heterozygous } \\
\text { mutation }\end{array}$ & $\begin{array}{l}\text { Positive; } \\
120 \mathrm{IU} / \mathrm{ml}\end{array}$ & $\begin{array}{l}\text { Positive; } \\
1720 \mathrm{IU} / \mathrm{ml}\end{array}$ & $\begin{array}{l}\text { Sulfasalazine, } \\
\text { Colchicine }\end{array}$ \\
\hline $\begin{array}{l}\text { Alpaycı } \\
\text { et al. }{ }^{8}\end{array}$ & 31 & $\mathrm{~F}$ & Typical FMF attacks & M694V homozygous mutation & $(-)$ & $(-)$ & $\begin{array}{l}\text { Methotrexate, } \\
\text { Prednisolone, } \\
\text { Sulfasalazine, } \\
\text { Etanercept, Colchicine }\end{array}$ \\
\hline $\begin{array}{l}\text { Nureki } \\
\text { et al. }{ }^{9}\end{array}$ & 42 & $\mathrm{~F}$ & $\begin{array}{l}\text { Recurrent fever, chest and } \\
\text { back pain }\end{array}$ & $\begin{array}{c}\text { R314R and M694I heterozygous } \\
\text { mutation }\end{array}$ & NA & NA & $\begin{array}{l}\text { Prednisolone, } \\
\text { sulfasalazine, } \\
\text { colchicine }\end{array}$ \\
\hline $\begin{array}{l}\text { Gök } \\
\text { et al. }{ }^{10}\end{array}$ & 27 & $\mathrm{~F}$ & $\begin{array}{l}\text { Febrile periodic abdominal } \\
\text { attacks }\end{array}$ & $\begin{array}{l}\text { M694V and } \\
\text { R202Q homozygote } \\
\text { mutation }\end{array}$ & $(-)$ & $(-)$ & $\begin{array}{l}\text { Methotrexate, } \\
\text { Sulfasalazine, } \\
\text { Prednisolone, } \\
\text { Hydroxychloroquine, } \\
\text { Tofacitinib, Colchicine }\end{array}$ \\
\hline $\begin{array}{l}\text { Matsuoka } \\
\text { et al. }{ }^{11}\end{array}$ & 75 & $\mathrm{~F}$ & $\begin{array}{c}\text { Chest pain, fever, pericardial } \\
\text { effusion }\end{array}$ & $\begin{array}{c}\text { E148Q heterozygous } \\
\text { Mutation }\end{array}$ & NA & $\begin{array}{l}\text { Positive; } \\
753.6 \\
\text { IU/ml }\end{array}$ & $\begin{array}{l}\text { Methotrexate, } \\
\text { Tacrolimus, } \\
\text { Tocilizumab, } \\
\text { Colchicine }\end{array}$ \\
\hline $\begin{array}{l}\text { Matsuoka } \\
\text { et al. }{ }^{11}\end{array}$ & 52 & $\mathrm{~F}$ & Arthralgia and fever & $\begin{array}{c}\mathrm{E} 148 \mathrm{O} / \mathrm{L} 110 \mathrm{P} \\
\text { compound heterozygous } \\
\text { mutation }\end{array}$ & NA & $\begin{array}{l}\text { Positive; } \\
186.2 \\
\text { IU/ml }\end{array}$ & $\begin{array}{c}\text { Methotrexate, } \\
\text { Abatacept, Colchicine }\end{array}$ \\
\hline
\end{tabular}

F: Female, FMF: Familial Mediterranean Fever, Age: years, Anti-CCP: Anti-Cyclic citrullinated peptide, RF: Rheumatoid factor, NA: not available (-): negative

In conclusion, clinicians should consider the possibility of coexistence between FMF and RA. And the coexistence should be kept in mind.

Etik; Bu yazıda sunulan olgu için sunulan bilgilerin akademik amaçlı kullanımı hakkında detaylı bilgileri de içeren imzalı "Bilgilendirilmiş onam formu" alınmıştır.

Ethics; For the case presented in this article, a signed "informed consent form" was obtained, which includes detailed information about the use of the information presented for academic purposes.

Yazar katkı durumu; Olgunun tanı ve takip süreci; BS tedavi süreci; BS Literatür taraması BS yazım aşaması; BS

Author contribution status; The concept of the study; BS design; BS literature review; BS collecting and processing data; BS statistics; BS writing phase; BS.

Yazarlar arasında çıkar çatışması yoktur.

The author declares no conflict of interest.

Finansal Destek: yoktur / Funding : none

doi: https://doi.org/10.33713/egetbd.889175

\section{REFERENCES}

1. Silva-Fernández L, Macía-Villa $C$, Seoane-Mato $D$, et al. The prevalence of rheumatoid arthritis in Spain. Sci Rep. 2020;10:21551.

2. Ulrich Scherer $H$, Häupl $T$, Burmester GR. Journal of Autoimmunity. 2020;110:1024002.

3. Tufan A, Lachmann HJ. Familial Mediterranean fever, from pathogenesis to treatment: a contemporary review. Turk J Med Sci. 2020;50:1591-610.

4. Portincasa P. Colchicine, Biologic Agents and More for the Treatment of Familial Mediterranean Fever. The Old, the New, and the Rare. Curr Med Chem. 2016;23:60-86.

5. Turan Y, Şendur ÖF, Berkit IA. Coexistence of Familial Mediterranean Fever and Rheumatoid Arthritis in A Case. Turk J Rheumatol. 2010;25:44-6.

6. Mori S, Yonemura K, Migita K. Familial Mediterranean fever occurring in an elderly Japanese woman with recentonset rheumatoid arthritis. Intern Medicine. 2013;52:385-8.

7. Migita K, Abiru S, Sasaki O, et al. Coexistence of familial Mediterranean fever and rheumatoid arthritis. Mod Rheumatol. 2014;24:212-6. 
8. Alpaycı M, Yazmalar L. Successful Treatment with Etanercept of Rheumatoid Arthritis Occurring in a Patient with Familial Mediterranean Fever. Turk J Phys Med Rehab. 2014;60:69-71.

9. Nureki SI, Ishii K, Fujisaki H, et al. Familial Mediterranean Fever With Rheumatoid Arthritis Complicated by Pulmonary Paragonimiasis. Intern Med. 2016;55:2889-92.

10. Gök K, Cengiz G, Erol K, Ozgocmen S. Tofacitinib Suppresses Disease Activity and Febrile Attacks in a Patient With Coexisting Rheumatoid Arthritis and Familial Mediterranean Fever. Acta Reumatol Port. 2017;42:88-90.

11. Matsuoka N, Iwanaga J, Ichinose $Y$, Fujiyama $K$, Tsuboi M, Kawakami A, Migita K. Two elderly cases of familial Mediterranean fever with rheumatoid arthritis. Int J Rheum Dis. 2014;21:1873-7.

12. Koga T, Kawashiri SY, Migita K, et al. Comparison of serum inflammatory cytokine concentrations in familial Mediterranean fever and rheumatoid arthritis patients. Scand J Rheumatol. 2018;47:331-3.

13. Livneh A, Langevitz $P$, Zemer $D$, et al. Criteria for the diagnosis of familial Mediterranean fever. Arthritis Rheum 1997;40:1879-85.

14. Aletaha D, Neogi T, Silman AJ, et al. 2010 Rheumatoid arthritis classification criteria: an American College of Rheumatology/European League Against Rheumatism collaborative initiative. Arthritis Rheum 2010;62:2569-81.

15. Yago T, Asano T, Fujita Y, Migita K.Fukushima J. Familial Mediterranean fever phenotype progression into anti-cyclic citrullinated peptide antibody-positive rheumatoid arthritis:a case report. Med Sci. 2020;66:160-6.

16. Singh JA, Furst DE, Bharat A, et al. 2012 update of the 2008 American College of Rheumatology recommendations for the use of disease-modifying antirheumatic drugs and biologic agents in the treatment of rheumatoid arthritis. Arthritis Care Res.2012;64:625-39.

17. Alayli G, Durmus D, Ozkaya O, Sen HE, Nalcacioglu $H$, Bilgici $A$, et al. Functional capacity, strength, and quality of life in children and youth with familial Mediterranean fever. Pediatr Phys Ther 2014;26:347-52.

18. Bodur H, Yurdakul FG, Duruoz MT, et al. Familial Mediterranean Fever: Health-Related Quality of Life and Associated Variables in a National Cohort. Archives of Rheumatology 36:159-66.

19. van Steenbergen HW, Aletaha D, Beaart-van de Voorde LJ, et al. EULAR definition of arthralgia suspicious for progression to rheumatoid arthritis. Ann Rheum Dis 2017;76:4916.

20. Inanir A, Yigit S, Karakus N, Tekin S, Rustemoglu A. Association of MEFV gene mutations with rheumatoid factor levels in patients with rheumatoid arthritis. J Investig Med. 2013;61:593-6 